\title{
Effect of Ketoprofen Co-Administration and Febrile State on Pharmacokinetics of Levofloxacin in Goats Following Intravenous Administration
}

\author{
H. Patel Jatin ${ }^{1 *}$, D. Vihol Priti ${ }^{2}$, A. Sadariya Kamlesh ${ }^{4}$, D. Patel Urvesh ${ }^{3}$, \\ D. Varia Rasesh ${ }^{1}$, K. Bhavsar Shailesh ${ }^{4}$ and M. Thaker Ashwin ${ }^{4}$
}

${ }^{1}$ Department of Pharmacology and Toxicology, ${ }^{2}$ Department of Veterinary Pathology, College of Veterinary Science and Animal Husbandry, Navsari Agricultural University, Navsari 396450, India

${ }^{3}$ Department of Pharmacology and Toxicology, College of Veterinary Science and Animal Husbandry, Junagadh Agricultural University, Junagadh 362015, India

${ }^{4}$ Department of Pharmacology and Toxicology, College of Veterinary Science and Animal Husbandry, Anand Agricultural University, Anand 388 001, India

*Corresponding author

\section{A B S T R A C T}

Keywords

Pharmacokinetic,

Levofloxacin,

Ketoprofen, Fever, Goat

Article Info

Accepted:

18 September 2018

Available Online:

10 October 2018
The pharmacokinetic of levofloxacin $(4 \mathrm{mg} / \mathrm{kg}$ ) was studied following intravenous administration of levofloxacin in ketoprofen (3 $\mathrm{mg} / \mathrm{kg})$ treated and febrile (Lipopolysaccharide induced) goats. The concentration of levofloxacin in plasma was detected by using High Performance Liquid Chromatography. No significant changes were reported in pharmacokinetic parameters following co-administration of levofloxacin with ketoprofen. While under febrile state, significant increase in area under plasma curve and decrease in total body clearance were observed. Integrating the pooled pharmacokinetic data generated from the present study, levofloxacin via intravenous administration (4 $\mathrm{mg} / \mathrm{kg}$ ) repeated at $12 \mathrm{~h}$ interval is sufficient to maintain plasma concentration above the $0.05 \mu \mathrm{g} / \mathrm{mL}$ MIC for most of the gram-positive and gram-negative microorganisms.

\section{Introduction}

Antibacterial and NSAIDs are used most frequently in multiple drug prescriptions. It is well documented that concurrently administered drugs may alter pharmacokinetics of one or both drugs. Levofloxacin is a third-generation fluoroquinolone with a wide spectrum of bactericidal activity. The drug is active against Gram-negative, Gram-positive and anaerobic bacteria including Pseudomonas species. It has enhanced activity against Streptococcus pneumoniae, Staphylococcus aureus and Enterococcus species, besides having good activity against Mycoplasma and Chlamydia (Davis and Bryson, 1994; Martinez et al., 2006). Ketoprofen is a routinely used as non- 
steroidal anti-inflammatory, analgesic and antipyretic agent in veterinary practice (Boothe, 1995). Pharmacokinetics of levofloxacin, administered as single drug were investigated in many species (Albarellos et al., 2005; Dumka and Srivastava, $2007^{\mathrm{ab}}$, Goudah, 2009; Varia et al., 2009; Goudah and Hasabelnaby, 2010; Patel et al., 2012 ${ }^{\mathrm{abc}}$, Goudah and Abo-El-Sooud, 2009; Patel et al., 2013). However, there is no information available on the influence of co-administration of ketoprofen and febrile state on the pharmacokinetic of levofloxacin in goats. Looking to possibility for interaction of ketoprofen and to reveal pharmacokinetic of levofloxacin in goat under febrile state, the study was undertaken to determine effect of ketoprofen and febrile condition on pharmacokinetics of levofloxacin in goat.

\section{Materials and Methods}

\section{Experimental animals}

The experiment was conducted on six healthy adult (2-3 years of age) Surti goat, weighing $28-32 \mathrm{~kg}$. Each animal was housed in a separate pen and provided standard ration with ad libitum water. Goats were kept under constant observation for two weeks before the commencement of the experiment and subjected to clinical examination to exclude the possibility of any diseases. The experimental protocol was approved by Institutional Animal Ethics Committee.

\section{Drug and chemical}

Levofloxacin infusion $(500 \mathrm{mg} / 100 \mathrm{~mL}$; Tavanic ${ }^{\circledR}$ Aventis Pharmaceutical Ltd, Bangalore) was procured from local pharmacy. Levofloxacin technical grade powder was procured from Moxi Laboratory Pvt. Ltd., Gujarat, India. Acetonitrile, Triethylamine, Perchloric acid (70\%) and Ortho-phosphoric acid (min. 58\%) (Analytical grade) were purchased from Merck Limited, Mumbai.

\section{Drug administration and sample collection}

All six animals were randomly allocated to receive injection of levofloxacin at the dose rate of $4 \mathrm{mg} / \mathrm{kg}$. A washout period of 2 weeks was observed between treatments. The intraveneous injection (4 $\mathrm{mg} / \mathrm{kg})$ was administered in jugular vein, while ketoprofen was administrated via. deep intramuscular (3 $\mathrm{mg} / \mathrm{kg}$ ) in gluteal muscle. Blood samples (3 $\mathrm{mL}$ ) were collected, before administration and at 5, 10, 15, 30 min and 1, 2, 4, 8, 12, 18, 24 and $36 \mathrm{~h}$ after concurrent intravenous and intramuscular administration of levofloxacin and ketoprofen respectively from contralateral jugular vein. Febrile state in goat was induced by injecting lipopolysaccharide (LPS) of Escherichia coli (O55:B5) at the dose rate of $0.2 \mu \mathrm{g} / \mathrm{kg}$ body weight intravenously (Verma and Roy, 2006). LPS was repeated at dose rate of 0.1 and $0.05 \mu \mathrm{g} / \mathrm{kg}$ at $12 \mathrm{~h}$ and $24 \mathrm{~h}$, respectively to maintain the febrile state up to $36 \mathrm{~h}$. Blood samples $(3 \mathrm{~mL})$ were collected, before administration and at 5, 10, 15, $30 \mathrm{~min}$ and $1,2,4,8,12,18,24$ and $36 \mathrm{~h}$ after intravenous administration of levofloxacin in febrile goats. Goats were monitored for any adverse reactions during the entire study period. Blood samples were subjected to centrifugation at $3000 \mathrm{~g}$ for $10 \mathrm{~min}$ and plasma samples was collected and preserved $-20{ }^{\circ} \mathrm{C}$, and analyzed within $48 \mathrm{~h}$ for determination of levofloxacin concentration.

\section{Analytical assay of levofloxacin and pharmacokinetic analysis}

Levofloxacin concentration in plasma samples was determined by reverse-phase High Performance Liquid Chromatography (HPLC) after extraction, using a reported assay (Varia et al., 2009) with minor modifications. The High Performance Liquid Chromatography 
(HPLC) apparatus (Laballiance, USA) comprised of quaternary gradient delivery pump (model AIS 2000), UV detector (model 500) and C18 column (Thermo ODS: $250 \mathrm{x}$ $4.6 \mathrm{~mm}$ ID) were used. Pharmacokinetic data integration was done by software "Clarity" (Version 2.4.0.190). Pharmacokinetic data of levofloxacin following intravenous injection in ketoprofen treated and in febrile goats were compared to intravenous injection of levofloxacin alone in goats (Patel et al., 2013)

Solution of pure enrofloxacin powder $(40 \mu \mathrm{l}$ of $0.5 \mathrm{mg} / \mathrm{mL}$ concentration) was utilized as an internal standard (IS). After adding internal standard in each plasma samples $(500 \mu \mathrm{L})$, it was deproteinized by addition of perchloric acid $(50 \mu \mathrm{l})$ and vortexed for one minute. This was followed by centrifugation at $3000 \mathrm{~g}$ for 10 minutes. An aliquot of supernatant was collected in clean vial and $20 \mu \mathrm{L}$ was injected into loop of HPLC system using $25 \mu \mathrm{L}$ glass syringe (Hamilton Bonaduz AG, Switzerland). The mobile phase consisted of a mixture of $1 \%$ triethylamine in water and acetonitrile $(85: 15 \mathrm{v} / \mathrm{v})$ adjusted to $\mathrm{pH} 3.0$ with orthophosphoric acid. Mobile phase was filtered by $0.45 \mu$ size filter (Ultipor N66Nylone 6,6 membrane, PALL Pharmalab filtration Pvt., Ltd., Mumbai) and degassed by ultrasonication. Thereafter mobile phase was pumped into column at a flow rate of 1.5 $\mathrm{mL} / \mathrm{min}$ at ambient temperature. The effluent was monitored at $290 \mathrm{~nm}$ wavelength.

Calibration curve was prepared daily for drug concentration ranging from 0.01 to $50 \mu \mathrm{g} / \mathrm{mL}$. The assay was sensitive (LLOD: $0.01 \mu \mathrm{g} / \mathrm{mL}$ ), reproducible and linearity was observed from 0.01 to $50 \mu \mathrm{g} / \mathrm{mL}\left(\mathrm{r}^{2}=0.99\right)$. The lower limit of quantification of the drug with a coefficient of variation was less than $8.36 \%$ for 0.01 $\mu \mathrm{g} / \mathrm{mL}$ concentration. The mean extraction recovery from plasma was $>82.81 \pm 3.83 \%$ at the spiked concentrations between 0.01 and 50 $\mu \mathrm{g} / \mathrm{mL}$. Precision and accuracy were determined using quality control (QC) samples at concentrations $0.05,1,2.5,10$ and $50 \mu \mathrm{g} / \mathrm{mL}$ (5 replicates each per day). The intraday and interday coefficients of variation for 5 QC samples were satisfactory with the relative deviations (RSD) of less than $9.77 \%$.

\section{PK/PD integration}

The peak plasma drug concentration $\left(\mathrm{C}_{\max }\right)$ and area under the curve $\left(\mathrm{AUC}_{(0-\infty)}\right)$ were applied in the calculation of the predictors of efficacy $\left(\mathrm{C}_{\max } / \mathrm{MIC}\right.$ and $\left.\mathrm{AUC}_{(0-\infty)} / \mathrm{MIC}\right)$ for levofloxacin following intravenous administration in ketoprofen treated and febrile goat. $\mathrm{MIC}_{90}$ of $0.05 \mu \mathrm{g} / \mathrm{mL}$ of levofloxacin has been taken into consideration to determine dosage of levofloxacin.

\section{Statistical analysis}

Levofloxacin plasma concentration and pharmacokinetic parameters of different treatment groups were compared by students' " $t$ " test using SPSS software (version 12.0.1).

\section{Results and Discussion}

Plasma levofloxacin concentrations at different time intervals following intravenous injection under febrile state and ketoprofen coadministered intramuscularly in goats is presented as semi logarithmic plot in Figure 1.

On concurrent administration of levofloxacin (4 mg/kg, IV) and ketoprofen (3 mg/kg, IM), the initial plasma concentration of levofloxacin at $2 \mathrm{~min}$ was $11.1 \pm 0.41 \mu \mathrm{g} / \mathrm{mL}$, which declined rapidly to $2.32 \pm 0.08 \mu \mathrm{g} / \mathrm{mL}$ at $1 \mathrm{~h}$ and the drug concentration of $0.015 \pm$ $002 \mu \mathrm{g} / \mathrm{mL}$ was detected up to $18 \mathrm{~h}$. Plasma drug concentration of $11.22 \pm 0.42 \mu \mathrm{g} / \mathrm{mL}$ observed at $2 \mathrm{~min}$ in febrile goats declined to $2.60 \pm 0.11 \mu \mathrm{g} / \mathrm{mL}$ at $1 \mathrm{~h}$, which was significantly higher as compared to plasma drug concentration found at $1 \mathrm{~h}$ in normal 
goats. Plasma drug concentrations observed were significantly higher from 1 to $18 \mathrm{~h}$ in febrile goats than normal goats except at $4 \mathrm{~h}$. The drug (levofloxacin) levels above the minimum inhibitory concentration (MIC: 0.05 $\mu \mathrm{g} / \mathrm{mL}$ ) were detected in plasma up to $12 \mathrm{~h}$ following co-administrated with ketoprofen and in febrile state. Various levofloxacin pharmacokinetic determinants that describe the absorption and elimination pattern after concurrent levofloxacin intravenous administration with ketoprofen intramuscular administration and under febrile state in goats are presented in Table 1.

No adverse effects or toxic manifestations were observed in goats following intravenous administration levofloxacin $(4 \mathrm{mg} / \mathrm{kg})$ in concurrent administration with ketoprofen (3 $\mathrm{mg} / \mathrm{kg}$, IM). In endotoxin induced febrile state, symptoms viz., increased respiration and pulse rate, decrease in feed intake, dryness of mouth and muzzle, and incoordination in movements were observed.

Following intravenous administration of levofloxacin in ketoprofen-treated goats, no significant changes in pharmacokinetic parameters were observed compared to pharmacokinetic parameters of levofloxacin in normal goats (Patel et al., 2013). Following intravenous administration of levofloxacin in febrile goats, no significant changes were observed with the mean values of important pharmacokinetic parameters viz. $\mathrm{Vd}_{\mathrm{ss}}, \mathrm{t}_{1 / 2 \alpha}$, $\mathrm{t}_{1 / 2 \beta}$, and MRT compared to levofloxacin administration in normal goats. The values of AUC $(13.48 \pm 0.48 \mu \mathrm{g} . \mathrm{h} / \mathrm{mL})$ and AUMC $\left(40.01 \pm 2.66 \mu \mathrm{g} \cdot \mathrm{h}^{2} / \mathrm{mL}\right)$ were significantly higher than the values obtained after levofloxacin administration in normal goats (Patel et al., 2013). The value of $\mathrm{Cl}_{\mathrm{B}}(0.29 \pm$ $0.009 \mathrm{~L} / \mathrm{h} / \mathrm{kg}$ ) was significantly lower than the values obtained after levofloxacin administration in normal goats $(0.35 \pm 0.022$ $\mathrm{L} / \mathrm{h} / \mathrm{kg}$ ) (Patel et al., 2013).
Following intravenous administration of levofloxacin in febrile goats, the significant decrease in the Clearance $\left(\mathrm{Cl}_{\mathrm{B}}\right)$ and increase in Area under plasma curve (AUC) may be due to endotoxin induced toxic and adverse effects on the kidneys, including direct vascular damage to the endothelium and platelet aggregation in renal glomerular capillaries. It also produces some functional changes including decrease in the renal blood flow and glomerular filtration rate and changes in the intra-renal hemodynamics (Jernigan et al., 1988, Hasegawa et al., 1999). Endotoxin could produce a metabolic acidosis, which would cause a decrease in urinary $\mathrm{pH}$ in febrile animals (Van Miert, 1990) and may favour reabsorption of drug from renal tubules. In addition decrease in systemic vascular pressure, central venous pressure, cardiac output (Salam Abdullah and Baggot, 1986), the peripheral blood flow (due increases in body temperature and to counter act loss of heat), gastrointestinal and hepatic blood flow, which has been reported in ruminants given E. coli endotoxin (Waxman et al., 2003). It is probable that the decrease in glomerular filtration rate induced by endotoxin plays an important role in the decrease of body clearance of drugs which are widely eliminated by the renal route, including levofloxacin. In addition to this the acute phase response induced by febrile state includes synthesis of acute phase hepatic proteins, including $\alpha_{1}$-acid glycoprotein, which binds some drugs and may produce a decrease in their clearance as levofloxacin has $22 \%$ degree of plasma protein binding (Goudah and Abo-El-Sooud, 2010).

It is suggested that the critical breakpoints determining the efficacy of fluoroquinolones are $\mathrm{C}_{\max } / \mathrm{MIC}_{90} \geq 8-10$, and $\mathrm{AUC}_{0-24} / \mathrm{MIC}_{90}$ $\geq 100$ to avoid bacterial resistance emergence (Dudley, 1991; Drusano et al., 1993; MadrasKelly et al., 1996; Walker, 2000; Toutain et al., 2002). 
Fig.1 Semilogarithmic plot of plasma concentrations after intravenous administration of levofloxacin (LFX) (4 mg/kg) in Ketoprofen (KTP)-treated $(3 \mathrm{mg} / \mathrm{kg})$ and febrile goats. Each point represents mean of six animals

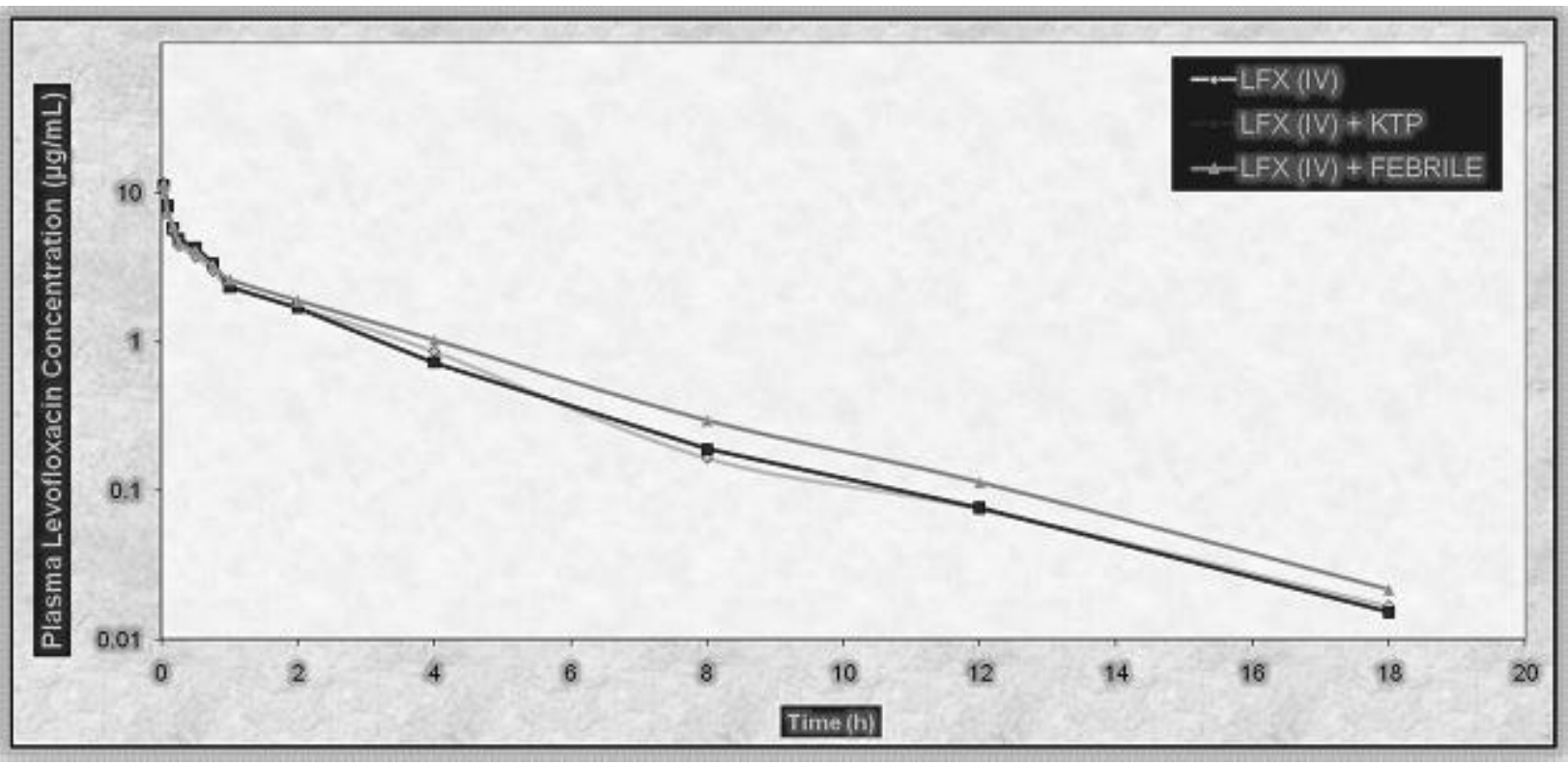

Table.1 Levofloxacin ( $4 \mathrm{mg} / \mathrm{kg}$ ) pharmacokinetic parameters following intravenous administration in ketoprofen treated $(3 \mathrm{mg} / \mathrm{kg})$ and febrile goats. (Mean $\pm \mathrm{SE}, \mathrm{n}=6$ )

\begin{tabular}{|c|c|c|c|c|}
\hline $\begin{array}{c}\text { Pharmacokinetic } \\
\text { Parameter }\end{array}$ & Unit & $\begin{array}{l}\text { Levofloxacin } \\
\text { (IV) }\end{array}$ & $\begin{array}{c}\text { Levofloxacin } \\
\text { (IV) and } \\
\text { Ketoprofen (IM) }\end{array}$ & $\begin{array}{l}\text { Levofloxacin (IV) } \\
\text { and Febrile State }\end{array}$ \\
\hline $\mathrm{Cp}^{0}$ & $\mu \mathrm{g} / \mathrm{mL}$ & $6.68 \pm 0.51$ & $7.41 \pm 0.61$ & $6.49 \pm 0.63$ \\
\hline $\mathbf{A}$ & $\mu \mathrm{g} / \mathrm{mL}$ & $4.75 \pm 0.50$ & $5.54 \pm 0.70$ & $3.37 \pm 0.88$ \\
\hline $\mathbf{B}$ & $\mu \mathrm{g} / \mathrm{mL}$ & $1.92 \pm 0.29$ & $1.86 \pm 0.13$ & $3.11 \pm 0.37$ \\
\hline$\alpha$ & $\mathrm{h}^{-1}$ & $1.27 \pm 0.13$ & $1.29 \pm 0.088$ & $1.31 \pm 0.19$ \\
\hline $\bar{\beta}$ & $\mathrm{h}^{-1}$ & $0.27 \pm 0.005$ & $0.27 \pm 0.004$ & $0.27 \pm 0.003$ \\
\hline$t_{1 / 2 \alpha}$ & $\mathrm{H}$ & $0.57 \pm 0.05$ & $0.54 \pm 0.03$ & $0.67 \pm 0.20$ \\
\hline$\overline{t_{1 / 2 \beta}}$ & $\mathrm{H}$ & $2.53 \pm 0.05$ & $2.56 \pm 0.04$ & $2.5 \pm 0.02$ \\
\hline $\mathbf{A U C}_{0-\infty}$ & $\mu \mathrm{g} \cdot \mathrm{h} / \mathrm{mL}$ & $11.65 \pm 0.71$ & $11.66 \pm 0.23$ & $13.48 \pm 0.43 *$ \\
\hline AUMC & $\mu \mathrm{g} \cdot \mathrm{h}^{2} / \mathrm{mL}$ & $30.17 \pm 3.99$ & $29.28 \pm 1.77$ & $40.01 \pm 2.66 \%$ \\
\hline $\mathbf{V} \mathbf{d}_{\mathrm{ss}}$ & $\mathrm{L} / \mathrm{kg}$ & $0.86 \pm 0.02$ & $0.85 \pm 0.02$ & $0.85 \pm 0.03$ \\
\hline $\mathrm{Cl}_{\mathbf{B}}$ & $\mathrm{L} / \mathrm{h} / \mathrm{kg}$ & $0.35 \pm 0.022$ & $0.34 \pm 0.006$ & $0.29 \pm 0.009 *$ \\
\hline MRT & $\mathbf{H}$ & $2.53 \pm 0.19$ & $2.5 \pm 0.10$ & $2.95 \pm 0.13$ \\
\hline
\end{tabular}

*Significant at $\mathrm{p}<0.05$ when compared with respective values of intravenous levofloxacin administered alone in goats (Patel et al., 2013).

$\mathrm{K}_{\mathrm{a}}$ : Absorption rate constant, B: Zero-time intercept of elimination phase, $\mathrm{t}_{1 / 2 \mathrm{ka}}$ : Absorption half-life, $\mathrm{t}_{1 / 2 \beta}$ : Elimination half-life, $\mathrm{C}_{\max }$ : Maximum drug concentration, $\mathrm{T}_{\max }$ : Time of maximum observed concentration in plasma, $\mathrm{AUC}_{0-\alpha}$ : Area under curve, AUMC: Area under first moment of curve, $\mathrm{Vd}_{\mathrm{ss}}$ : Volume of distribution at steady state, $\mathrm{Cl}_{\mathrm{B}}$ : Total body clearance, MRT: Mean residence time, 
Calculation of surrogate parameter following intravenous administration of levofloxacin (4 $\mathrm{mg} / \mathrm{kg}$ body weight) in ketoprofen-treated and febrile goats resulted in $\mathrm{Cp}^{0} / \mathrm{MIC}$ ratio (MIC: $0.05 \mu \mathrm{g} / \mathrm{ml}$ ) of 148.20 and 129.80 respectively, which exceeds the recommended ratio of $\mathrm{Cp}^{0} / \mathrm{MIC}$ ratio.

For AUC/MIC ratio at MIC: $0.05 \mu \mathrm{g} / \mathrm{mL}$ and $0.1 \mu \mathrm{g} / \mathrm{mL}$ were found higher than 100 in ketoprofen-treated (233.20 and 116.60) and febrile condition (269.60 and 134.80) respectively. Following intravenous administration, average minimum inhibitory concentration i.e $0.05 \mu \mathrm{g} / \mathrm{ml}$ of levofloxacin maintained in plasma up to $12 \mathrm{~h}$ in ketoprofen treated goats and in febrile goats. Considering the values of $\mathrm{C}_{\max } / \mathrm{MIC}$ and $\mathrm{AUC} / \mathrm{MIC}$ ratios obtained in the present study, it can be concluded that levofloxacin administered intravenous at the dose rate of $4 \mathrm{mg} / \mathrm{kg}$ at 12 $\mathrm{hr}$ interval may be efficacious against bacteria with MIC values under $0.05 \mu \mathrm{g} / \mathrm{mL}$ satisfactorily.

Levofloxacin can successfully coadministrated with Ketoprofen for combating inflammatory conditions and in febrile condition without alteration of dosage regimen of levofloxacin.

Moreover integrating the pooled pharmacokinetic data generated from the present study, levofloxacin via intravenous administration $(4 \mathrm{mg} / \mathrm{kg})$ repeated at $12 \mathrm{~h}$ interval is sufficient to maintain plasma concentration above the $0.05 \mu \mathrm{g} / \mathrm{mL}$ MIC for most of the gram-positive and gram-negative microorganisms.

\section{Acknowledgement}

The authors express thanks to College of Veterinary Science and Animal Husbandry, AAU, Anand for providing necessary facilities and funding.

\section{References}

Albarellos, G.A., Ambros, L.A. and Landoni, M.F. 2005. Pharmacokinetics of levofloxacin after single intravenous and repeat oral administration to cats. J. Vet. Pharmacol. Ther., 28: 363-369.

Boothe, D.M., 1995. The analgesic, antipyretic, anti-inflammatory drugs. In: Veterinary Pharmacology and Therapeutics $8^{\text {th }}$ (Ed.), Iowa State University Press, Ames, pp. 444-445.

Davis, R. and Bryson, H.M. 1994. Levofloxacin: A review of its antibacterial activity, pharmacokinetics and therapeutic efficacy. Drugs, 47: 677-700.

Drusano, G.L.; Johnson, D.E.; Rossen, M. and Standiford, S. C. 1993. Pharmacodynamis of a fluroquinolone antimicrobial agent in a neutropenic rat model of Pseudomonas sepsis. Antimicrob. Agents Chemother. 37:483-490.

Dudley, M.N. 1991. Pharmacodynamics and pharmacokinetics of antibiotics with special reference to fluroquinolones. Am. J. Med. 91: 45-50.

Dumka, V.K. and Srivastava, A.K. 2007 ${ }^{\mathrm{a}}$. Kinetic disposition, urinary excretion and dosage regimen of subcutaneously administered levofloxacin in cross bred calves. Iran. J. Vet. Res., 8: 313-318.

Dumka, V.K. and Srivastava, A.K. 2007 ${ }^{\mathrm{b}}$. Disposition kinetics, urinary excretion and dosage regimen of levofloxacin formulation following single intravenous administration in crossbred calves. Vet. Res. Commun., 31: 873-879.

Goudah, A. 2009. Pharmacokinetics of levofloxacin in male camels (Camelus dromedarius). J. Vet. Pharmacol. Therap., 2: 296-299.

Goudah, A. and Abo-El-Sooud, K. 2009. Pharmacokinetics, urinary excretion and milk penetration of levofloxacin in lactating goats. J. Vet. Pharmacol. Ther., 32: 101-104.

Goudah, A. and Hasabelnaby, S. 2010. Disposition kinetics of levofloxacin in 
sheep after intravenous and intramuscular administration. Vet. Med. Int., 2010: 1-6.

Hasegawa, T., Takagi, K., Kitaichi, K. 1999. Effects of bacterial endotoxin on drugs pharmacokinetics. Nagoya J Med. Sci. 62, $11-28$.

Jernigan, A.D., Hatch, R.C., Wilson, R.C., Brown, J., Crowell, W.A., 1988. Pathologic changes and tissue gentamicin concentrations after intravenous gentamicin administration in clinically normal and endotoxemic cats. Am. J. Vet. Res. 49, 613-617.

Madras-Kelly, K.J.; Ostergaard, B.E.; BakerHovde, L. and Rotschafer, J.C. 1996. Twenty four-hour area under the concentration time curve/MIC ratio as a generic predictor of fluoroquinolone antimicrobial effect by using three strains of Pseudomonas aeruginosa and an in vitro pharmacodynamics model. Antimicrob. Agents Chemother. 40: 627-632.

Martinez, M., McDermott, $\mathrm{P}$ and Walker, R. 2006. Pharmacology of the fluoroquinolones: A perspective for the use in domestic animals. Vet. J., 172: 10-28.

Patel J. H., Vihol P. D., Patel U. D., Bhavsar S. K. and Thaker A. M. 2013. Pharmacokinetics of levofloxacin following subcutaneous administration in goat. J Vet. Pharmacol Toxicol. 12(1-2): 35-38.

Patel, J.H., Varia, R.D., Vihol, P.D., Ratndeep, S., Patel, U.D., Bhavsar, S.K., and Thaker, A.M. 2012 . Pharmacokinetics and Bioavailability of Levofloxacin in White Leg Horn Birds. Indian Vet. J., 89(8): 6971.

Patel, U.D., Patel, J.H., Bhavsar, S.K. and Thaker, A.M. 2012 ${ }^{\text {b }}$. Pharmacokinetics of levofloxacin following intravenous and subcutaneous administration in sheep. Asian J. Anim. Vet. Adv., 7:85-93.

Patel, U.D., Patel, J.H., Varia, R.D., Patel, H.B, Bhavsar, S.K., and Thaker, A.M. 2012 . Disposition kinetic of levofloxacin in experimentally induced febrile model of sheep. J. Pharmacol Toxicol., 7: 11-19.

Salam Abdullah, A. and Baggot, J.D. 1986. Influence of induced disease states on the disposition kinetics of imidocarb in goats. $J$ Vet. Pharmacol Ther. 9:192-197.

Toutain, P.L.; DelCastillo, J.R.E. and Bousquet $M^{\prime}$ elou A. 2002. The pharmacokinetic pharmacodynamic approach to a rational dosage regimen for antibiotics. Res. Vet. Sci. 73(2):105-114.

Vann Miert, A. 1990. Influence of febrile disease on the pharmacokinetics of veterinary drugs. Ann. Recher. Vet. 21:11-28.

Varia, R.D., Patel, J.H., Patel, U.D., Bhavsar, S.K. and Thaker, A.M. 2009. Disposition of levofloxacin following oral administration in broiler chickens. Israel $J$. Vet. Med., 64: 118-121.

Verma, D.K., Roy, B.K., 2006. Milk kinetics of gatifloxacin after single dose intravenous administration in healthy and febrile goats. Indian J. Pharmacol., 38, 366-367.

Walker, R.D. 2000. The use of fluoroquinolones for companion animal antimicrobial therapy. Aust. Vet. J. 78(2): 84-90.

Waxman, S.; SanAndres, M.D.; Gonzalez, F.; DeLucas, J.J.; SanAndres, M.I. and Rodriguez, C. 2003. Influence of Escherichia coli endotoxin-induced fever on the pharmacokinetic behavior of marbofloxacin after intravenous administration in goats. J. Vet. Pharmacol. Ther. 26:65-69.

\section{How to cite this article:}

Patel Jatin, H., D. Vihol Priti, A. Sadariya Kamlesh, D. Patel Urvesh, D. Varia Rasesh, K. Bhavsar Shailesh and Thaker Ashwin, M. 2018. Effect of Ketoprofen Co-Administration and Febrile State on Pharmacokinetics of Levofloxacin in Goats Following Intravenous Administration. Int.J.Curr.Microbiol.App.Sci. 7(10): 2477-2483. doi: https://doi.org/10.20546/ijcmas.2018.710.287 